\title{
Perceived Fairness of Demand-based Pricing for Restaurants
}

\section{Variable pricing in restaurants_-for example, by day part or weekends versus weekdays- is likely to be okay with customers provided the different price schemes seem fair.}

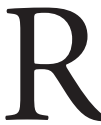
evenue management consists of two strategic levers: duration control and demand-based pricing. ${ }^{1}$ Some restaurant managers try to manage duration by changing their service delivery (for example, by speeding up the delivery process), ${ }^{2}$ but have been reluctant to apply demand-

\footnotetext{
${ }^{1}$ See, for example: S.E. Kimes and R.B. Chase, "The Strategic Levers of Yield Management," Journal of Service Research, Vol. 1, No. 2 (November 1998), pp. 156-166; and S.E. Kimes, R.B. Chase, S. Choi, E.N. Ngonzi, and P.Y. Lee, "Restaurant Revenue Management," Cornell Hotel and Restaurant Administration Quarterly, Vol. 40, No. 3 (June 1998), pp. 40-45.

${ }^{2}$ See, for example: B. Sill and R. Decker, "Applying Capacity-management Science: The Case of Browns Restaurants," Cornell Hotel and Restaurant Administration Quarterly, Vol. 40, No. 3 (June 1998), pp. 22-30; S.E. Kimes, D.I. Barrash, and J.E. Alexander, "Developing a Restaurant Revenuemanagement Strategy," Cornell Hotel and Restaurant Administration Quarterly, Vol. 34, No. 5 (October 1999), pp. 18-30; and B. Sill, "Capacity Management: Making Your Service-delivery System More Productive," Cornell Hotel and Restaurant Administration Quarterly, Vol. 33, No. 1 (February 1991), pp. 77-87.
}

based pricing for fear of possible customer dissatisfaction. While restaurants do use demand-based pricing when offering promotions such as happy hours and early bird specials, they have been loathe to vary prices by time of day, day of week, or table location.

Restaurant managers' fears may, in fact, have some basis in reality. As explained in a moment, researchers have found that customers refuse to patronize companies that they perceive as unfair. ${ }^{3}$ If demand-based pricing in restaurants is viewed as unfair by patrons, the restaurant could suffer a loss of business.

${ }^{3}$ See: D. Kahneman, J.L. Knetsch, and R.H. Thaler, "Fairness and the Assumption of Economics," Journal of Business, Vol. 59 (October 1986), pp. S285-S300; and R.H. Thaler, "Mental Accounting and Consumer Choice,” Marketing Science, Vol. 4, No. 3 (Summer 1985), pp. 199-214. 
The intent of the research described here was to determine how customers react to several demand-based-pricing strategies in the restaurant industry. Specifically, we examined the perceived fairness of the following demand-based approaches: (1) differential lunch-versus-dinner pricing, (2) differential weekday-versus-weekend pricing, (3) time-of-day pricing (e.g., early bird specials), (4) coupon pricing (including restrictions), and (5) table-location pricing (e.g., charging extra for a table with a view). Furthermore, we explored whether framing those demand-based-pricing mechanisms as discounts rather than surcharges would make them more acceptable (fair) to restaurant patrons.

\section{Issues to Consider}

Restaurants are often reluctant to use demandbased pricing because of potential customer backlash. If increased prices cannot be justified either by higher associated costs or through certain desirable conditions, customers may view demandbased-pricing policies as unfair. The issue of fairness has been studied extensively in a variety of non-hospitality industries, ${ }^{4}$ and one of us (Sheryl Kimes) studied perceived fairness in the hotel and airline industries. ${ }^{5}$ In general, it was found that fair behavior on the part of operators is instrumental to the maximization of their long-term profits.

Consumers may perceive demand-based pricing as being unfair for at least two reasons. First, they may view the higher prices during high-demand times to be more than their reference price, or their reference price may already have been shifted downward because of lower prices during low-demand periods. In

${ }^{4}$ See, for example: M.C. Campbell, "Why Did You Do That? The Important Role of Inferred Motive in Perceptions of Price Fairness," Journal of Product and Brand Management, Vol. 8, No. 2 (1999), pp. 145-152; M.C. Campbell, "Perceptions of Price Unfairness: Antecedents and Consequences," Journal of Marketing Research, Vol. 36, No. 2 (June 1999), pp. 187-199; Kahneman, Knetsch, and Thaler, pp. S285-S300; P.J. Kaufmann, G. Ortmeyer and N.C. Smith, "Fairness in Consumer Pricing," Journal of Consumer Policy, Vol. 14 (1991), pp. 117-140; Thaler, pp. 199-214; and J.E. Urbany, T.J. Madden, and P.R. Dickson, "All's Not Fair in Pricing: An Initial Look at the Dual Entitlement Principle," Marketing Letters, Vol. 1, No. 1 (1989), pp. 17-25.

${ }^{5}$ S.E. Kimes, "Perceived Fairness of Yield Management," Cornell Hotel and Restaurant Administration Quarterly, Vol. 29, No. 1 (February 1994), pp. 22-29. either event, the "new," higher regular prices may be perceived as less fair than before. Second, the restaurant may not be seen as providing more value for the higher price, which would violate consumer beliefs about "dual entitlement" (as explained below). We first discuss the effect that demand-based pricing can have on consumer reference prices, followed by an examination of the potential effect of dual-entitlement beliefs on perceived fairness of demand-based-pricing strategies.

Reference prices. The terms "reference transaction" and "reference price" are often used when discussing fairness. A reference transaction is how customers think a transaction should be conducted and a reference price is how much customers think a service (or product) should cost. Reference prices can come from the price last paid, the price most frequently paid, and what other customers say they paid for similar offerings, as well as from market prices and posted prices. For example, customers may know that they generally pay about $\$ 25$ for dinner at a particular restaurant, and so their reference price for dinner at that restaurant is $\$ 25$.

To assess a transaction's fairness, customers often rely on reference prices. ${ }^{6}$ For consumers to perceive demand-based pricing as fair, their reference prices would have to shift in line with the restaurant's variable-pricing schedule. This may be difficult for operators to achieve for two reasons. First, the low price used during lowdemand periods may become the consumer's reference price and may make future purchases at the regular or peak rate seem unfair. Second, consumers may believe that the restaurant is charging them higher prices to reap higher profits without having increased the customer's value, violating the patron's beliefs about dual entitlement, which is discussed next.

Dual entitlement. The principle of dual entitlement holds that most customers believe that they are entitled to a reasonable price and that firms are entitled to a reasonable profit. ${ }^{7}$

Customers are likely to view demand-based pricing as unbalancing that relationship by either

\footnotetext{
${ }^{6}$ Kahneman, Knetsch, and Thaler, pp. S285-S300.

${ }^{7}$ See: Ibid.; and Thaler, pp. 199-214.
} 
increasing the value to the firm without increasing the value to the customer, or by decreasing the value to the customer without a substantial enough price reduction. As a result, customers may view such transactions as unfair. For example, if a restaurant increases its menu prices for no apparent reasons, it is increasing the firm's value without increasing the customer's, and customers may then view the transaction as unfair. Similarly, if a restaurant imposes substantial restrictions on customers in exchange for only a somewhat lower price, customers may view the transaction as unfair.

Two hypotheses emerge from the principle of dual entitlement. ${ }^{8}$ First, customers feel that raising the price to maintain profits is fair. Therefore, if costs increase, customers consider it reasonable for the price to increase accordingly. For example, after the foot-and-mouth disease outbreak in the United Kingdom in 2000, meat prices increased and some restaurants raised their menu prices to account for the increased costs. Based on the principle of dual entitlement, those price increases would be viewed as fair. Second, customers believe that raising the price simply to increase profits is unfair. For example, after Hurricane Andrew in the early 1990s, many companies charged extremely high prices for food, water, tools, and supplies. As predicted by the principle of dual entitlement, consumers considered these practices to be extremely unfair.' (Indeed, in some instances such price gouging is also illegal.)

If the principle of dual entitlement holds true, some forms of revenue management may be perceived as unfair. Customers generally view price differences as fair if they perceive them to be justified, but consumers view unjustified price increases to be unfair. If customers believe that the transaction is different from the reference transaction only in price, they may believe that the firm is receiving more than its reference price and is behaving unfairly. One way of increasing the perceived fairness of demand-based pricing is the use of price fences, which are discussed next.

\footnotetext{
${ }^{8}$ Kahneman, Knetsch, and Thaler, pp. S285-S300.

${ }^{9}$ M.C. Campbell, pp. 145-152.
}

Rate fences. Price fences are designed to allow customers to segment themselves based on their willingness to pay, their behavior, and their needs. ${ }^{10}$ Price fences offer consumers discounted prices but impose rules and regulations at every level of discount to balance the perceived value for the different market segments, and to avoid automatically offering a discount to customers who are willing to pay a higher price. ${ }^{11}$ Fences may include requirements for advance purchase, advance payment, cancellation and change

\section{If a restaurant increases its menu prices for no apparent reasons, customers may view subsequent transactions as unfair.}

restrictions, refund penalties, time-of-use restrictions, and minimum-purchase requirements. For example, airlines offer many different fares, but to qualify for a deeply discounted fare, customers may have to make their reservation and purchase the ticket far in advance, stay over a Saturday night, and accept steep cancellation or rebooking penalties. The traveler who is unwilling to accept the restrictions does not qualify for the lower rate and usually ends up paying a higher fare.

The purpose of a rate fence is to create customer segments and justify why different people pay different prices. To be perceived as fair, fences need to be logical, transparent, upfront, and fixed so that they cannot be circumvented. ${ }^{12}$ Essentially, there are two types of rate fence that companies can use to customize their prices: physical and non-physical. ${ }^{13}$

${ }^{10}$ R.B. Hanks, R.P. Noland, and R.G. Cross, "Discounting in the Hotel Industry: A New Approach," Cornell Hotel and Restaurant Administration Quarterly, Vol. 33, No. 3 (June 1992), pp. 40-45.

${ }^{11}$ Ibid.

${ }^{12}$ D.J. Bennett, "Discount-fare Market Research, 19811983," 63 $3^{\text {rd }}$ Annual Meeting of the Transportation Research Board, January 1984, p. 2.

${ }^{13}$ Hanks, Noland, and Cross, pp. 40-45. 
EXHIBIT 1

Fairness ratings of rate fences

Demand-based pricing fences

Differential lunch-versus-dinner pricing expressed as

- Surcharge

- Discount

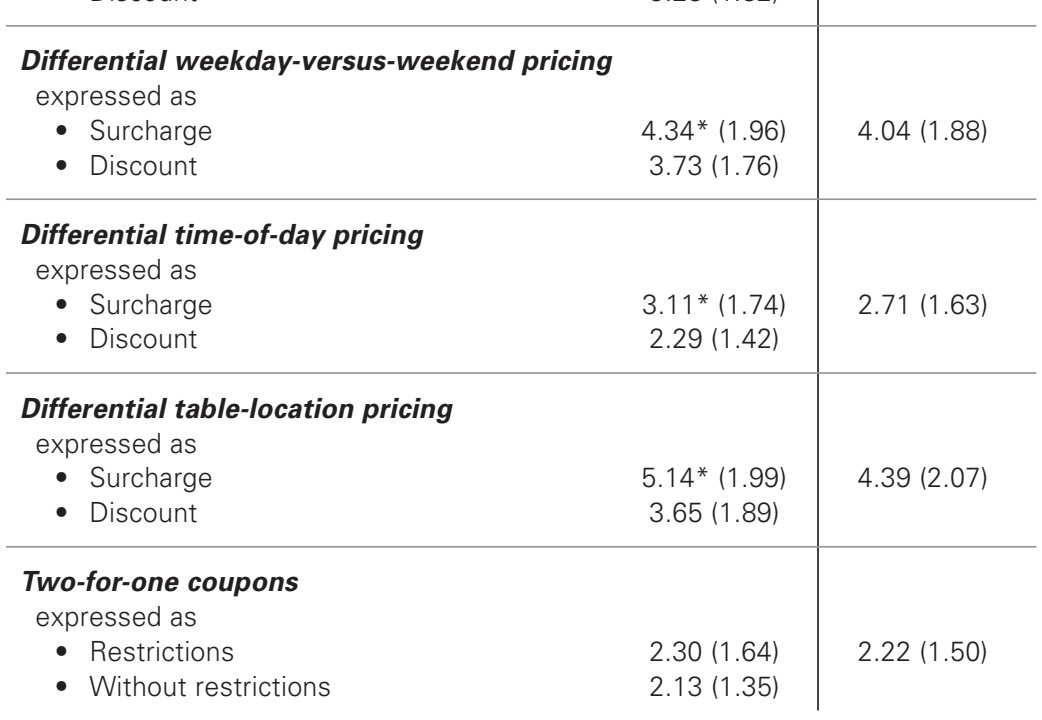

Notes: The Likert-type scale used was 1 = "extremely fair" to 7 = "extremely unfair," and "STD" = standard deviation.

*The difference between the two framing conditions is significant at $p>0.05$, two-tailed. who make a reservation over a month ahead of time might pay less), buyer characteristics (frequent customers might pay less, or get freeof-charge extras), and controlled availability (customers with coupons will pay less).

In our study we explored the perceived fairness of five potential fences for restaurants, specifically the three time-based fences (differential lunchversus-dinner, weekday-versus-weekend, and time-of-day pricing), one physical fence (table location), and one controlled-availability fence (two meals for the price of one).

Framing of price differences. We also investigated how customers react to the way price differences are presented. Specifically, we wanted to know whether a fence framed as a price decrease would be evaluated more favorably than the same fence presented as a price increase. We turned to behavioral decision theory and prospect theory to help address our question. ${ }^{15}$ Behavioral decision theory holds that the way in which an alternative is presented (its framing) affects its evaluation by potential customers. Presentations that emphasize customer gains are preferable to economically equivalent frames that emphasize customer losses.

For example, consider a restaurant with a static menu that decides to establish two sets of menu prices. The restaurant can present the price differences in two ways: it can either present the lunch prices as 20-percent lower than the dinner prices (framed as a gain from the diner's perspective) or it can present the dinner prices as 20-percent higher than the lunch prices (framed as a loss). The situations are economically equivalent, but behavioral decision theory holds that customers will view the "reduced" prices more favorably, and that the restaurant should frame the price difference accordingly. In this study, we explored the effect of framing on the perceived fairness of price fences.

\section{The Study}

In an attempt to answer the question of how customers react to demand-based pricing, we conducted an in-person survey of 157 hotel guests at Cornell University's Statler Hotel. All survey

${ }_{15}$ D. Kahneman and A. Tversky, "Prospect Theory: An Analysis of Decision under Risk," Econometrica, Vol. 47, No. 2 (March 1979), pp. 263-291.
${ }^{14}$ R.J. Dolan and H. Simon, Power Pricing (New York: The Free Press, 1996). 
interviews were conducted by trained individuals who approached hotel guests in the lobby and asked them to participate in a short survey.

Five different scenarios were developed that each described one of the following demandbased pricing fences: lunch-versus-dinner pricing, weekday-versus-weekend pricing, time-of-day pricing, coupon pricing, and table-location pricing. Respondents were asked to evaluate the fairness of each scenario, with " 1 " being extremely fair and " 7 " being extremely unfair. Two demographic-data questions also were asked, namely, frequency of dining out and age, and the interviewers recorded each guest's gender.

Two versions of the survey were developed. The same questions were asked on each survey, but the price changes were presented variably either as a discount or as a surcharge. We wanted to see whether customers reacted differently based on how the price differences were framed. A mix of question types was asked on each survey. Each respondent completed only one survey.

\section{Results}

Our findings are presented in Exhibits 1 and 2, and next we discuss those findings on the various demand-based-pricing mechanisms.

Lunch-versus-dinner pricing. Many restaurants offer similar lunch and dinner menus but charge lower prices for lunch. The lower prices are usually associated with smaller portion sizes. Our first question concerned pricing of lunch and dinner menus. Respondents were presented with either the premium or the discount scenario (the discount condition is presented in parentheses for the purposes of this analysis), and were asked to evaluate its fairness on our Likert-type scale ( 1 = extremely fair and 7 = extremely unfair).

A restaurant has two menus: lunch and dinner.

The dinner (lunch) menu has slightly higher (lower) prices even though the menu items are the same as on the lunch (dinner) menu.

Respondents viewed different prices for lunch and dinner menus as reasonably fair (mean $=$ 3.40). The wording of the question did not seem to matter much. When the dinner price was presented as "slightly higher," the average rating was 3.53, while when the lunch price was presented as "slightly lower," the average rating was 3.28.

\section{EXHIBIT 2}

\section{Consumers' fairness perceptions of demand-based pricing tools}

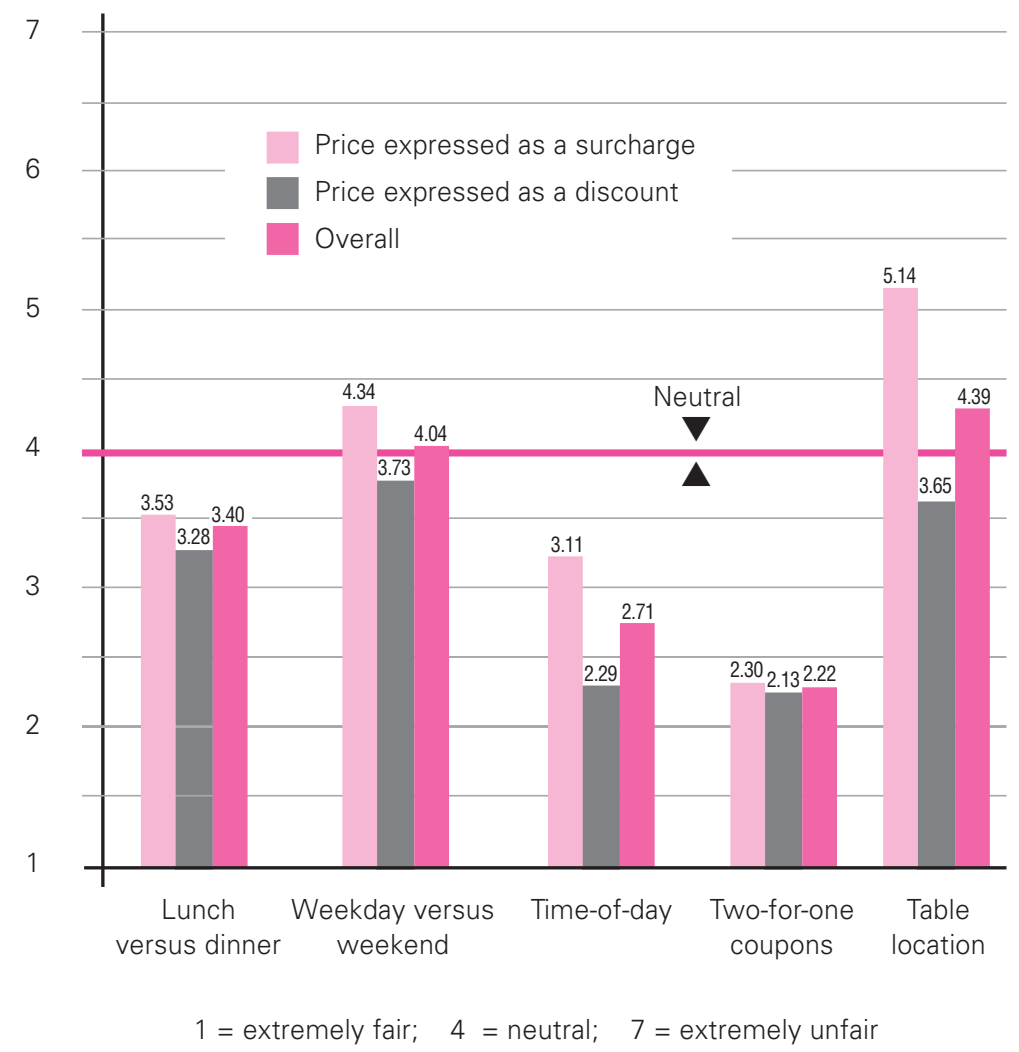

The mean difference of 0.25 between the two scenarios was not significant $(t=0.40)$.

The results imply that restaurants can charge different prices for the same menu items during lunch and dinner periods without risking customers' perceptions of unfairness. (There is an assumption, however, that paying more for dinner means that the customer will get larger portions or a special presentation relative to the lunch-menu fare.)

Weekday-versus-weekend pricing. Most restaurants have a higher demand on weekend evenings than they do during the rest of the week. Proponents of demand-based pricing would argue that weekend menu prices should be raised to respond to that high demand. Most restaurant 
managers are reluctant to pursue this policy explicitly because they fear customer dissatisfaction. Instead, many restaurants implicitly charge high prices for weekend dinners through such practices as chalkboard menus and high-priced "specials."

Our second question concerned different prices for weekend and weekday menus.

A restaurant has different dinner menus for weekdays and weekends. The menus are the same except that the weekend (weekday) prices are higher (lower) than the weekday (weekend) prices.

Respondents viewed different prices for weekend and weekday menus as still acceptable (mean = 4.04). In this case, however, the framing of the question seemed to matter. When the weekday menu was presented as having lower prices, respondents viewed the practice as significantly more acceptable $($ mean $=3.73)$ than when the weekend menu was presented as having higher prices (mean $=4.34 ; t=2.06$ ).

Those results imply that customers view different prices for weekend and weekday menus as relatively acceptable. If a restaurant decides to pursue this practice, it should carefully word the new policy so that the weekday menus are presented as offering a discount off the weekend-menu prices.

Time-of-day pricing. Many restaurants offer happy hours and early bird specials, and some have expanded into other time-of-day pricing schemes. For example, in Hong Kong the Peninsula Hotel's Kowloon restaurant charges different prices for its buffet depending on the time of day. The practice has been popular and financially successful. The Sheraton hotel in Stockholm has experimented with time-of-day pricing for its main restaurant and has thereby increased revenue. Our third question dealt with how customers evaluated time-of-day pricing.

A restaurant has two sets of prices. If you eat dinner between 6 PM and 8 PM (before 6 PM or after 8 PM), you pay 20 percent more (less) than the normal price and if you eat before 6 PM or after 8 PM (between 6 PM and 8 PM), you pay the regular price. The restaurant advertises this policy and makes sure customers are aware of the prices.

Respondents viewed time-of-day pricing as fair $($ mean $=2.71)$, and the wording of the question seemed to matter. When the scenario was presented as 20-percent lower prices before 6:00 PM or after 8:00 PM, the respondents viewed the price variability as significantly fairer (mean $=2.29)$ than when the price differential was presented as being 20-percent higher between 6:00 PM and 8:00 PM (mean = 3.11; $t=3.24)$.

Those results imply that restaurants can, in general, use time-of-day pricing without incurring customer wrath. If a restaurant decides to use timeof-day pricing, however, it should be careful to frame the prices as a discount, not as a premium.

Two-for-one coupons. Many restaurants participate in two-for-one coupon promotions in an attempt to build demand during slow periods and to make the restaurant attractive to those who might not try it without an incentive. Whatever the restaurant's goal, consumers who use two-forone coupons often purchase additional items, which leads to increased revenue for the restaurant. In the fourth question, respondents were asked to evaluate this scenario.

A restaurant participates in a two-for-one coupon program. Customers can use the coupons for two-for-one dinners at any time except on Friday or Saturday night (at any time on Sundays through Thursdays).

Respondents considered two-for-one coupon programs to be very fair (mean $=2.22$ ), and the framing of the question did not seem to matter. When the coupons were offered with restrictions (e.g., anytime except on Friday or Saturday night), respondents rated the policy as marginally less acceptable $($ mean $=2.30)$ than when they were presented with no restrictions (mean $=2.13$ ), but the difference was not significant $(t=0.66)$.

Those results imply that two-for-one coupons can be a valuable and popular tool for restaurants. Customers view their use as extremely fair, and a restaurant should be able to use the coupons to help build demand during slow periods.

Table location. Our final scenario concerned charging different prices based on the physical location of the tables. Some restaurants, most notably those located in sports stadiums and those with scenic window views, already explicitly charge a premium for desirable tables. For example, TGIFridays at Phoenix's Bank One Stadium charges a higher price for tables located near the field than it does for tables farther away. Other restaurants implicitly charge a premium for desirable tables, for example, when a customer can obtain preferential seating by tipping the maître $d$ '. Such an allowance is essentially charging more for the 
desirable table (although the maitre $d^{\prime}$ is making the additional money, not the restaurant). Respondents were asked to evaluate the following scenario.

A restaurant has a beautiful view and most customers like to have tables near the window so they can better see the view. The restaurant charges a $\$ 20$ premium (offers a $\$ 20$ discount) for tables next to (away from) the window.

Respondents viewed this practice as moderately unacceptable $($ mean $=4.39)$, but their evaluation varied by how the question was framed. When the price was presented as a $\$ 20$ premium, respondents viewed it as significantly less acceptable (mean $=$ 5.14) than when it was presented as a $\$ 20$ savings (mean $=3.65 ; t=4.80)$.

Our findings suggest that restaurants have to be careful if they decide to charge a higher price for premium tables, as consumers perceive this practice as somewhat unfair. If restaurants advertise a lower price for non-premium tables, customers are likely to view that policy as more acceptable than if the restaurant explicitly charges a higher price for premium tables. Also, although not tested in this study, a strong rationale for discriminatory tablelocation pricing might make it more acceptable. For example, it might be perceived as somewhat unfair in restaurants where the view is not a core part of the value proposition. However, where table location is part of the core-value proposition-such as in a revolving restaurant in the highest building in a metropolis or inside sports venues-differential pricing might be more acceptable to customers. Also, restaurants can add physical fences in addition to table location (e.g., having a separate section for corporate clients or VIP regulars), and "hide" the surcharge in minimum per-guest checks or high cover charges.

\section{Summary and Conclusions}

Our results show that restaurant patrons consider demand-based pricing in the form of coupons (two for the price of one), time-of-day, and lunchversus-dinner pricing as fair. Variable weekdayversus-weekend pricing was perceived as neutral to slightly unfair. Table-location pricing was seen as somewhat unfair, with potential negative consumer reaction to that practice. Furthermore, we explored whether framing demand-based pricing as discounts or surcharges would make a difference. We found that demand-based pricing presented as discounts made the differential prices seem fairer in the consumers' eyes, and therefore less likely to have a negative effect on consumers' perceptions and reactions.

Our findings provide restaurant operators with some useful guidelines, but those do not guarantee that all guests may willingly accept demand-basedpricing practices. Therefore, when developing demand-based pricing using fences, restaurant operators must make sure that the rate fences are easy to explain and administer, and that customers can understand the reasoning behind them. This will make it easier for front-line employees to pacify unhappy or confused customers, and to recover the service if necessary. Also, the positioning of demandbased pricing to staff members and to customers should be as a win-win situation. It needs to be emphasized that the variable pricing allows patrons to choose prices that suit their needs and, by having tight fences, patrons who see high value in a good view, a desirable table, or eating dinner during peak times are much more likely to get the capacity and service they value. ${ }^{16}$ Accordingly, increasing profitability via demand-based pricing does not have to come at the expense of customer satisfaction and loyalty.

${ }^{16}$ J. Wirtz, J.P.T. Ho, and P.G. Patterson, "Yield Management: Resolving Potential Customer and Employee Conflicts," The NUS Business School Research Paper Series, No. 2001-026 (Mkt), 2001, National University of Singapore.
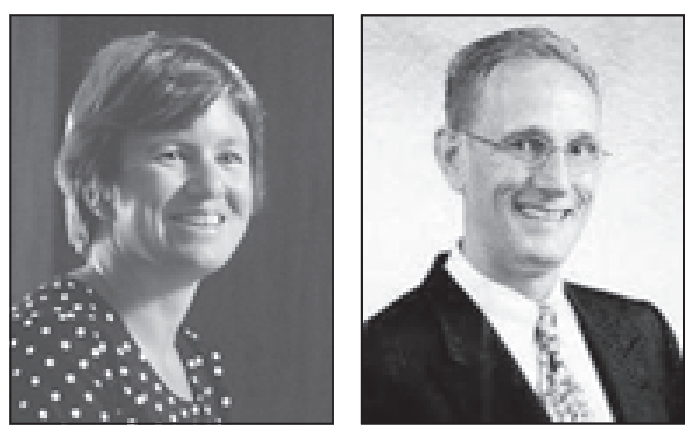

Sheryl E. Kimes, Ph.D. (above, left), is a professor at the Cornell University School of Hotel Administration (sek6@cornell.edu). Jochen Wirtz, Ph.D. (above, right), is an associate professor at the NUS Business School, National University of Singapore (bizwirtz@nus.edu.sg). The authors gratefully acknowledge the assistance provided by research students Breffni Noone, Carl Oldsberg, and Chua Hsiao Wei, and the authors thank James Hisle, managing director of Cornell's Statler Hotel, and Jeannette P.T. Ho, director of revenue management, Swissôtel the Stamford \& Raffles The Plaza, for their support and feedback.

(C) 2001, Cornell University; an invited article. 